\title{
Pengaruh L14 terhadap Peningkatan Kontraksi pada Kala I Persalinan
}

\author{
Neneng Siti Lathifah ${ }^{1}$, Ledy Octaviani Iqmy ${ }^{2}$ \\ ${ }^{1,2}$ Prodi Kebidanan Fakultas Kedokteran Universitas Malahayati, Indonesia \\ Email: nenengmalahayati@gmail.com
}

\begin{abstract}
The Influence of L14 on Increasing Contractions in the First Stages Labor Mother. The old partus is one of the causes of maternal death. Based on the date The Renstra of Provincial Health Office (2015) found that the old average partus in the world caused maternal mortality by $8 \%$, in Indonesia by $9 \%$ and in Lampung province by $0,63 \%$. The purpose of this study is to determine the effect of L14 against increasing contraction in the first stages labor mother in BPM Lia Maria Bandar Lampung Regency 2018. This type of research uses quantitative research with quasy experiment. The population in this study were all patients inpartu in the first stages labor mother at BPM Lia Maria Bandar Lampung 2018. Amounted to 83 people. Samples to 42 people. Technic Sampling Purposive Sampling With sample criteria divided into two, namely inclusion and exclusion. The data collection tool used in this research is to fill in the observation sheet and fill partograph. The statistical test used is T-Test. Statistical test results obtained p-value $0.000<0.05$. For practice land or BPM can be used as a solution that massage at the L14 point given to the mother in part at the active phase affects the increase in contraction, so that it can speed up the labor process and without harmful side effects.
\end{abstract}

Keywords: Increase contraction, L14, The first stage of labor

\begin{abstract}
Abstrak: Pengaruh L14 terhadap Peningkatan Kontraksi pada Kala I Persalinan. Partus lama merupakan salah satu penyebab kematian ibu. Berdasarkan data Renstra Dinas Kesehatan Propinsi Lampung (2015) didapatkan bahwa partus lama rata-rata di dunia menyebabkan kematian ibu sebesar 8\%, di Indonesia sebesar 9\% dan di propinsi lampung sebesar 0,63\%. Tujuan penelitian mengetahui Pengaruh L14 Terhadap Peningkatan Kontraksi Pada Kala I Persalinan Di BPM Lia Maria Bandar Lampung Tahun 2018. Penelitian kuantitatif dengan quasi eksperimen. Populasi semua pasien inpartu kala I di BPM Lia Maria Bandar Lampung tahun 2018 berjumlah 83 orang. Sampel berjumlah 42 orang dengan teknik pengambilan sampel purposive sampling kriteria sampel dibedakan menjadi dua, yaitu inklusi dan eksklusi. Instrumen penelitian lembar observasi dan mengisi partograf. Uji statistik yang digunakan adalah T-Test. Hasil penelitian didapat $p$-value $0,000<0,05$. Saran Bagi lahan praktik atau BPM dapat dijadikan sebagai salah satu solusi bahwa pemijatan pada titik L14 yang diberikan pada ibu Inpartu pada kala I fase aktif mempengaruhi peningkatan kontraksi, sehingga dapat mempercepat proses persalinan dan tanpa efek samping yang membahayakan.
\end{abstract}

Kata kunci: Peningkatan Kontraksi, L14, Kala I Fase Aktif

Persalinan merupakan hal yang fisiologis yang dialami oleh setiap orang,akan tetapi kondisi fisiologis tersebut dapat menjadi patologis apabila seorang ibu tidak mengetahui kondisi yang fisiologis dan seorang penolong atau tenaga kesehatan tidak memahami bagaimana suatu persalinan dikatakan fisiologis dan bagaimana penatalaksanaanya sehingga dapat membantu menurunkan angka kematian ibu sesuai dengan MDGs 2015 yang berganti SDGs (Sustainable Development Goals). Persalinan adalah proses pengeluaran janin yang terjadi selama kehamilan cukup bulan (37-42 minggu), lahir spontan dengan presentasi belakang kepala yang berlangsung selama 18 jam produk konsepsi dikeluarkan sebagai akibat kontraksi teratur, progresif, sering dan kuat yang nampaknya tidak saling berhubungan bekerja dalam keharmonisan untuk melahirkan bayi (Walyani dkk, 2016).

Menurut Survei Demografi Dan Kesehatan Indonesia (SDKI) tahun 2012, angka kematian ibu diindonesia masih tinggi sebesar 359 per 100.000 kelahiran hidup. Angka ini sedikit menurun jika dibandingkan dengan SDKI tahun 1991, yaitu sebesar 390 per 100.000 kelahiran hidup. Angka ini sedikit menurun meskipun tidak terlalu signifikan. (Info Data dan Informasi Kementrian Kesehatan RI , 2014)

Partus lama merupakan salah satu penyebab kematian ibu. Berdasarkan data 
Renstra Dinas Kesehatan Propinsi Lampung (2015) didapatkan bahwa partus lama rata-rata di dunia menyebabkan kematian ibu sebesar $8 \%$, di indonesia sebesar $9 \%$ dan di propinsi lampung sebesar $0,63 \%$.

Partus lama dapat dipengaruhi oleh kondisi psikologis ibu yaitu ketakutan. Ketakutan merupakan faktor utama yang menyebabkan rasa nyeri dalam persalinan, yang seyogyanya normal dan tanpa rasa nyeri yang berarti. Ketakutan mempunyai pengaruh yang tidak baik pula terhadap his dan lancarnya pembukaan (Rohani et al, 2011).

Pada primipara lama persalinan pada kala I mempunyai durasi yang lebih lama dibandingkan dengan multipara, dimana lama persalinan kala I pada primigravida berlangsung kira-kira 13 jam, sedangkan pada multigravida kira-kira 7 jam. Lamanya persalinan kala satu pada primipara ini menyebabkan rasa nyeri yang dialami juga lebih lama sehingga resiko mengalami keletihan akan lebih besar yang berakibat pada respon emosi berupa cemas, tegang, takut bahkan panik. Hal tersebut menunjukkan bahwa pada primipara partus lama dan kematian bayi mempunyai risiko yang lebih besar dibanding pada multipara. Mengingat hal tersebut bahwa manajemen nyeri persalinan perlu diperhatikan bagi petugas kesehatan terutama perawat maternitas untuk mengurangi risiko kematian ibu dan bayi (Sulistyawati dan Esty nugraheni, 2012).

Banyak metode yang dilakukan untuk menurunkan nyeri pada persalina, baik secara farmakologi maupun non farmakologi. Penggunaan metode farmakologi mempunyai efektifitas yang lebih baik dibanding dengan metode non farmakologi, namun penggunaan metode farmakologi sering menimbulkan efek samping dan kadang tidak memiliki efek yang diharapkan. Sedangkan Metode nonfarmakologi selain menurunkan nyeri pada persalinan juga mempunyai efek non-invasif, sederhana, efektif, dan tanpa efek yang membahayakan (Budiarti, 2011).

Penelitian yang dilakukan oleh Brown, Douglas dan Flood (2001) dengan menggunakan 10 metode non farmakologi yang dilakukan pada 46 orang didapatkan bahwa teknik pernapasan, relaksasi, akupresur, dan massage merupakan teknik yang paling efektif menurunkan nyeri saat persalinan (Budiarti, 2011).

Titik akupresur yang digunakan untuk induksi persalinan ada beberapa titik diantaranya adalah SP6 dan L14. Akupresur pada titik ini diyakini untuk merangsang melepaskan oksitosin dan kelenjar pituitary yang pada gilirannya merangsang kontraksi rahim untuk meningkatkan proses persalinan atau mengelola nyeri persalinan (Budiarti, 2011).

Titik L14 secara umum memiliki efek menghilangkan rasa sakit dan merangsang kontraksi. Penekanan pada titik L14 ini diyakini dapat membantu energi tubuh mendorong bayi bergerak turun melewati jalan lahir.

Di Indonesia akupresur sudah banyak diminati masyarakat dan dikembangkan sebagai salah satu tehnik pengobatan alternatif. Akupresur untuk mengelola persalinan juga sudah mulai dikembangkan di beberapa Rumah sakit di Indonesia dan dilakukan sebagai salah satu intervensi dalam mengelola persalinan. Penggunaan akupresur dalam mengelola persalinan juga sudah diterapkan oleh beberapa bidan di Garut, namun pengaruh penggunaan akupresur terhadap lama persalinan itu sendiri belum pernah diteliti.

Akupresur adalah tindakan yang sangat sederhana, mudah dilakukan, memiliki efek samping yang minimal, dan aplikasi prinsip healingtouch pada akupresur menunjukkan perilaku caring yang dapat mendekatkan hubungan terapeutik bidan dan pasien (Budiarti, 2011).

Teknik akupresur sebagai salah satu metode non farmakologi diharapkan dapat membantu bidan dalam persiapan ibu dan keluarga menghadapi persalinan sehingga kebutuhan ibu selama persalinan untuk mendapatkan pengalaman yang menyenangkan dengan rasa nyeri yang minimal dapat terpenuhi. Berdasarkan latar belakang di atas peneliti tertarik untuk mengetahui pengaruh akupresur terhadap peningkatan kontraksi kala I persalinan. Pada penelitian ini secara spesifik akan didefinisikan pengaruh akupresur pada titik L14 terhadap peningkatan kontraksi pada kala I persalinan.

\section{METODE}

Jenis penelitian ini menggunakan penelitian kuantitatif dengan quasy eksperiment. Disain ini tidak mempunyai pembatasan yang ketat terhadap randomisasi, dan pada saat yang sama dapat mengontrol ancaman-ancaman validitas. Disebut eksperimen semu karena eksperimen ini belum atau tidak memiliki ciri-ciri rancangan eksperimen sebenarnya, karena variabel-variabel yang seharusnya dikontrol atau dimanipulasi tidak dapat atau sulit dilakukan. Dalam karya tulis ilmiah ini penulis mengambil kasus pengaruh L14 terhadap peningkatan kontraksi pada kala I persalinan di BPM Lia Maria Bandar 
Lampung. Waktu penelitian dilakukan pada April s/d Juli 2018. Populasi dalam penelitian ini adalah semua pasien inpartu kala I di BPM Lia Maria Bandar Lampung tahun 2018 berjumlah 83 orang. Sampel pada penelitian ini adalah semua pasien inpartu kala I di BPM Lia Maria Bandar Lampung tahun 2018 berjumlah 42 orang. Dengan kriteria sampel dibedakan menjadi dua, yaitu inklusi dan eksklusi. Alat pengumpulan data terbagi dalam dua instrument, yaitu instrument A lembar observasi, intrumen B mengenai lama persalinan. Teknik yang digunakan dalam pengolahan data, yaitu editing, coding, processing, dan cleaning. Teknik analisa data yang digunakan adalah analisis univariat dan analisis bivariat. Penelitian ini dilakukan dengan beberapa tahap yaitu setelah mendapat persetujuan oleh pihak tempat penelitian, peneliti mengidentifikasi calon responden yang sesuai dengan kriteria inklusi yang telah ditetapkan, calon responden yang sesuai dengan kriteria diberikan informasi mengenai tujuan dan prosedur penelitian yang dilakukan kemudian diminta sebagai responden dengan menandatangani informed concent. Peneliti melakukan observasi yaitu dengan menilai kontraksi sebelum melakukan Akupresur L14 dengan cara posisikan jari peneliti diatas perut ibu (Bagian Pusat) hitung kontraksi selama 10 menit, Catat hasil di lembar observasi. Lakukan akupresur L14 di daerah antara tulang metacarpal 1 dan 2 sebanyak 30 kali memutar searah jarum jam. Ulangi langkah 3-5 hingga pemeriksaan dalam berikutnya. Peneliti mengobservasi lama persalinan kala I, yaitu: Lama persalinan didefinisikan melalui lembar observasi partograf. Lama persalinan dilihat dari pembukaan serviks 4 cm sampai dengan pembukaan serviks $10 \mathrm{~cm}$ (lengkap). Kerangka konsep penelitian adalah suatu uraian dan visualisasi hubungan atau kaitan antara konsep satu terhadap konsep yang lainnya, atau antara variabel yang satu dengan variabel yang lainnya dari masalah yang ingin diteliti. (Notoatmodjo, 2014).

Analisis yang digunakan adalah uji statistik uji T-test dependent. Ho ditolak jika $p$ value $\leq 0,05$ berarti ada hubungan yang signifikan antara kedua variabel yang diteliti dan Ho gagal ditolak. jika $p$-value $\geq 0,05$ berarti tidak ada hubungan yang signifikan (Hastono, 2010).

\section{HASIL}

\section{A. ANALISIS UNIVARIAT}

Tahap pertama dari analisis data adalah analisis univariat, maka dapat diketahui gambaran karakteristik dan distribusi subyek penelitian yaitu sebagai berikut:

\section{Tabel 1. Nilai Rata-rata Sebelum Dilakukan Akupressure L14 terhadap Peningkatan Kontraksi pada Kala I Persalinan}

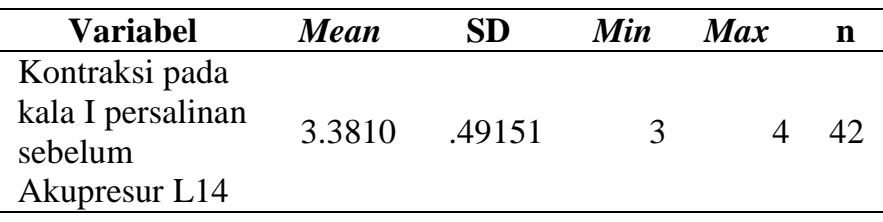

Berdasarkan hasil analisis data di atas, rata-rata kontraksi pada ibu Inpartu kala I fase aktif yang sebelum dilakukan pemijatan pada titik L14 adalah 3,3810 (3 kali dalam 10 menit) dengan skor kontraksi minimal 3 kali dalam 10 menit dan maksimal 4 kali dalam 10 menit.

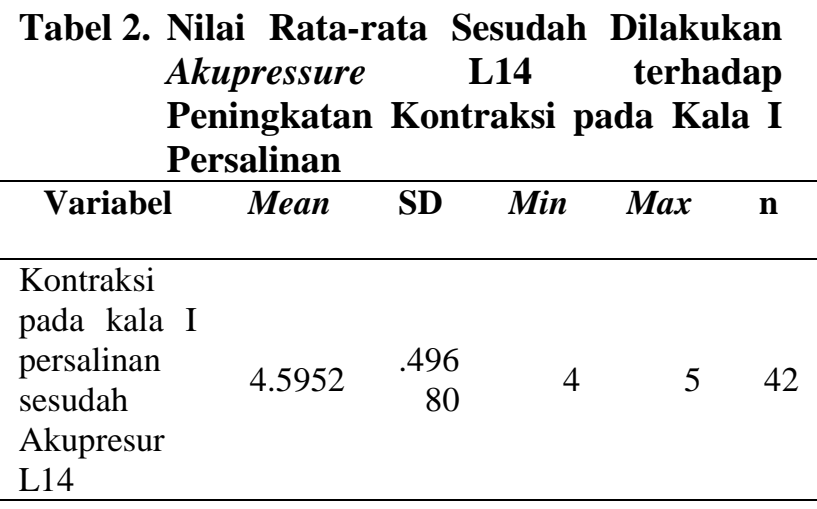

Berdasarkan hasil analisis data di atas, rata-rata kontraksi pada ibu Inpartu kala I fase aktif sesudah dilakukan pemijatan pada titik L14 adalah 4,5952 (5 kali dalam 10 menit) skor kontraksi minimal 4 kali dalam 10 menit dan maksimal 5 kali dalam 10 menit.

\section{B. ANALISIS BIVARIAT}

Tabel 3. Pengaruh akkupressure L14 terhadap Peningkatan Kontraksi pada Kala I Persalinan

\begin{tabular}{lllcc}
\hline \multicolumn{1}{c}{ Variabel } & Mean & SD & $\begin{array}{c}\boldsymbol{p}- \\
\text { value }\end{array}$ & $\mathbf{n}$ \\
\hline $\begin{array}{l}\text { Sebelum Akupresur } \\
\text { L14 }\end{array}$ & 3.3810 & .49151 & 0,000 & 42 \\
\hline $\begin{array}{l}\text { Sesudah } \\
\text { Akupresur L14 }\end{array}$ & 4.5952 & .49680 & 0,000 & 42 \\
\hline
\end{tabular}


Berdasarkan analisis bivariat dengan uji statistik didapatkan nilai $p$-value $0,000<0,05$, maka dapat disimpulkan bahwa ada pengaruh yang signifikan antara peningkatan kontraksi sebelum pemijatan L14 dan sesudah pemijatan L14 pada ibu Inpartu kala I fase aktif.

\section{PEMBAHASAN}

\section{UNIVARIAT}

Peningkatan kontraksi sebelum dilakukan pemijatan L14 terhadap ibu Inpartu kala I fase aktif di BPM Lia Maria Bandar Lampung Tahun 2018. Hasil penelitian didapatkan rata-rata kontraksi pada ibu yang belum dilakukan pemijatan L14 pada kala I persalinan fase aktif adalah 3,3810 (3 kali dalam 10 menit) dengan skor kontraksi minimal 3 kali dalam 10 menit dan maksimal 4 kali dalam 10 menit.

Peningkatan kontraksi sesudah dilakukan pemijatan L14 terhadap ibu Inpartu kala I fase aktif di BPM Lia Maria Bandar Lampung Tahun 2018. Hasil penelitian di dapatkan bahwa ratarata peningkatan kontraksi sesudah dilakukan pemijatan pada titik L14 terhadap ibu Inpartu kala I fase aktif adalah 4,5952 (5 kali dalam 10 menit) skor kontraksi minimal 4 kali dalam 10 menit dan maksimal 5 kali dalam 10 menit.

Memberikan asuhan yang memadai selama persalinan dalam upaya mencapai pertolongan persalinan yang bersih dan aman, dengan memberikan aspek sayang ibu dan sayang bayi. (Maternity, et al, 2016).

Penyebab kelainan his: sering dijumpai pada primigravida tua dan inersia sering dijumpai pada multi gravida, faktor herediter, emosi dan kekuatan memegang peranan penting. (Ai Yeyeh dan Lia Yulianti, 2010).

Akupresur adalah perkembangan terapi pijat yang berlangsung seiring dengan perkembangan ilmu akupunktur karena teknik pijat akupresur adalah turunan dari ilmu akupunktur. Teknik dalam terapi ini menggunakan jari tangan sebagai pengganti jarum tetapi dilakukan pada titik-titik yang sama seperti yang digunakan pada terapi akupunktur (Hartono, 2012).

Titik akupresur yang biasa digunakan untuk induksi persalinan diantaranya adalah L14. His (kontraksi uterus) adalah kontraksi otot-otot rahim pada persalinan. Pada bulan terakhir dari kehamilan dan sebelum persalinan dimulai, sudah ada kontraksi rahim yang disebut his. Walaupun his merupakan suatu kontraksi dari otot-otot rahim yang fisiologis, akan tetapi bertentangan dengan kontraksi fisiologis lainnyadan bersifat nyeri.

Perasaan nyeri tergantung juga pada ambang nyeri dari penderita, yang ditentukan oleh kondisi jiwanya. Kontraksi rahim bersifat otonom, artinya tidak dipengaruhi oleh kemauan, namun dapat dipengaruhi dari luar, misalnya rangsangan oleh jari-jari tangan (Rohani et al, 2011).

Titik akupresur yang biasa digunakan untuk induksi persalinan diantaranya adalah L14, dan SP6. Akupresur pada titik ini di yakini untuk merangsang melepaskan oksitosin dari kelenjar pituitary yang pada gilirannya merangsang kontraksi rahim untuk meningkatkan proses persalinan atau mengelola nyeri persalinan.

Titik L14 atau he ku terletak antara tulang metacarpal pertama dan kedua pada bagian distal lipatan pada kedua tangan. Meridian usus besar ini berjalan menyusuri tepi luar lengan naik ke bahu,sampai di bahu bercabang ke tengkuk mencapai benjolan ruas tulang leher 7 (cervical 7) dan tulang punggung 1 dan kembali ke bahu Di bahu meridian ini bercabang sebuah cabangnya ke bawah turun melintasi paru-paru mencapai usus besar. Penekanan pada titik ini berguna untuk mengintensifkan kontraksi dan menuntun sie bergerak ke bawah.

Titik L14 merupakan titik utama masalah rahim. Efek yang dihasilkan oleh penekanan pada titik L14 adalah memperbaiki energi yang tidak seimbang, tersumbat atau kurang disepanjang organ atau meridian yang melewatinya (Budiarti, 2011).

Pada fase aktif persalinan, frekuensi dan lama kontraksi uterus umumnya meningkat (kontraksi dianggap adekuat jika terjadi tiga kali atau lebih dalam waktu 10 menit dan berlangsung selama 40 detik atau lebih) dan terjadi penurunan bagian terbawah janin. Berdasarkan kurve friedman, diperhitungkan pembukaan pada primigravida $1 \mathrm{~cm} / \mathrm{jam}$ dan pembukaan multigravida $2 \mathrm{~cm} / \mathrm{jam}$ (Rohani et al, 2011).

Hasil penelitian ini didukung penelitian yang dilakukan Budiarti (2011) hasil pengukuran lama persalinan pada kelompok ibu yang mendapatkan akupresur pada titik L14 menunjukkan $60,4 \%$ lama persalinan $\leq 6$ jam dan $39,6 \%$ pada kelompok yang tidak mendapat akupresur. Menurut peneliti peningkatan kontraksi merupakan akibat dari respon tubuh yang seimbang. Dimana tubuh dapat memproduksi hormon dengan baik sehingga memicu terjadinya peningkatan kontraksi yang cukup besar. Selain itu peningkatan kontraksi juga dapat terjadi akibat respon sentuhan dari luar, seperti dilakukanya pemijatan pada titik L14 
secara teratur yang terletak antara tulang metacarpal pertama dan kedua pada bagian distal lipatan pada kedua tangan yang di lakukan diselasela waktu kontraksi.

\section{BIVARIAT}

Hasil penelitian ini menunjukkan rata-rata uji beda peningkatan kontraksi terhadap ibu Inpartu kala I fase aktif sebanyak 1.21429. Hasil uji statistik didapatkan nilai $p$-value $0,000<0,05$, maka dapat disimpulkan ada pengaruh yang signifikan antara peningkatan kontraksi sebelum pemijatan L14 dan sesudah pemijatan L14 pada ibu Inpartu kala I fase aktif.

Partus lama dapat dipengaruhi oleh kondisi psikologis ibu yaitu ketakutan. Ketakutan merupakan faktor utama yang menyebabkan rasa nyeri dalam persalinan, yang seyogyanya normal dan tanpa rasa nyeri yang berarti. Ketakutan mempunyai pengaruh yang tidak baik pula terhadap his dan lancarnya pembukaan (Rohani et al, 2011).

Pada primipara lama persalinan pada kala I mempunyai durasi yang lebih lama dibandingkan dengan multipara, dimana lama persalinan kala I pada primigravida berlangsung kira-kira 13 jam, sedangkan pada multigravida kira-kira 7 jam. Lamanya persalinan kala satu pada primipara ini menyebabkan rasa nyeri yang dialami juga lebih lama sehingga resiko mengalami keletihan akan lebih besar yang berakibat pada respon emosi berupa cemas, tegang, takut bahkan panik. Hal tersebut menunjukkan bahwa pada primipara partus lama dan kematian bayi mempunyai risiko yang lebih besar dibanding pada multipara. Mengingat hal tersebut bahwa manajemen nyeri persalinan perlu diperhatikan bagi petugas kesehatan terutama perawat maternitas untuk mengurangi risiko kematian ibu dan bayi. (Sulistyawati dan Esty Nugraheni, 2012).

Titik L14 secara umum memiliki efek menghilangkan rasa sakit dan merangsang kontraksi. Penekanan pada titik L14 ini diyakini dapat membantu energi tubuh mendorong bayi bergerak turun melewati jalan lahir.

Titik L14 atau he ku terletak antara tulang metacarpal pertama dan kedua pada bagian distal lipatan pada kedua tangan. Meridian usus besar ini berjalan menyusuri tepi luar lengan naik ke bahu,sampai di bahu bercabang ke tengkuk mencapai benjolan ruas tulang leher 7 (cervical 7) dan tulang punggung 1 dan kembali ke bahu. Di bahu meridian ini bercabang sebuah cabangnya ke bawah turun melintasi paru-paru mencapai usus besar. Penekanan pada titik ini berguna untuk mengintensifkan kontraksi dan menuntun sie bergerak ke bawah.

Berdasarkan hasil penelitian didapatkan sebagain besar kontraksi ibu Inpartu mengalami peningkatan. setelah dilakukan pemijatan pada titik L14 yang terletak antara tulang metacarpal pertama dan kedua pada bagian distal lipatan pada kedua tangan. Hal ini sesuai dengan teori Budiarti (2011) titik L14 merupakan titik utama masalah rahim. Efek yang dihasilkan oleh penekanan pada titik L14 adalah memperbaiki energi yang tidak seimbang, tersumbat atau kurang disepanjang organ atau meridian yang melewatinya dan dapat merangsang pelepasan oksitosin dari kelenjar hipofisis, yang secara langsung merangsang kontraksi rahim.

Menurut peneliti pemijatan akupresur pada titik L14 memiliki efek yang lebih baik pada peningkatan kontraksi terhadap ibu Inpartu kala I fase aktif. Pemijatan akupresur pada titik L14 dapat merangsang pelepasan oksitosin dan kelenjar pituitary yang pada gilirannya merangsang kontraksi rahim untuk meningkatkan proses persalinan.

Selain itu pemijatan akupresur pada titik L14 selain dapat meningkatkan kontraksi uterus pada persalinan juga dapat mengelola nyeri persalinan. titik L14 selain merangsang hormon oksitosin untuk mempercepat persalinan namun juga dapat merangsang hormon endorpin sehingga semakin banyak hormon endorpin yang dikeluarkan oleh tubuh maka rasa nyeri pada saat bersalin akan berkurang dikarenakan ibu merasa lebih tenang dan tidak gelisah.

Respon nyeri setiap ibu pada masa persalinan berbeda beda. Nyeri persalinan yang tidak terkontrol dapat merangsang peningkatan katekolamin yang menyebabkan gangguan pada kontraksi uterus sehingga terjadi inersia uteri apabila tidak dikoreksi akan menyebabkan terjadinya partus lama. Faktor yang dapat menyebabkan nilai nyeri berbeda beda atau bervariasi dan menunjukan perubahan yang relatif kecil dan reaksi terhadap nyeri (Aprina, $\mathrm{dkk}, 2015)$. Manifestasi fisiologis dari nyeri yang paling sering adalah peningkatan nadi dan kecepatan pernafasan, pupil berdilatasi/melebar, peningkatan tekanan darah, dan ketegangan otot. Peningkatan tegangan otot merupakan yang paling didasarkan karena bisa menghalangi kemajuan persalinan. Ibu dalam persalinan seringkali menguatkan otot-otot tulang selama kontraksi dan tetap tidak bergerak (Maryunani, 2010).

Pijatan ringan yang dilakukan dapat meningkatkan relaksasi otot sehingga 
memutuskan siklus Feartension-pain (takuttegang-nyeri) (Sunarsih, 2017).

\section{SIMPULAN}

Berdasarkan hasil analisis dan pembahasan yang telah dijabarkan pada bab 4 maka dapat diambil kesimpulan yaitu :

1. Kontraksi sebelum dilakukan pemijatan pada titik L14 pada ibu inpartu selama kala I fase aktif persalinan di dapatkan rata-rata kontraksi adalah 3,3810 (3 kali dalam 10 menit), dengan tingkat kontraksi minimal 3,00 (3 kali dalam 10 menit) dan maksimal 4,00 (4 kali kontraksi dalam 10 menit).

2. Kontraksi sesudah dilakukan pemijatan pada titik L14 pada ibu inpartu selama kala I fase aktif persalinan di dapatkan rata-rata kontraksi adalah 4,5952 (4 kali dalam 10 menit), dengan tingkat kontraksi minimal

\section{DAFTAR PUSTAKA}

Aprina, dkk. 2017. Relaksasi Progresif terhadap Intensitas Nyeri Post Operasi BPH (Benigna Prostat Hyperplasia). Jurnal Kesehatan, Vol 8, No 2, E-ISSN 2548 5695.

Budiarti, K Dewi. 2011. Hubungan Akupresur Dengan Tingkat Nyeri dan Lama Persalinan Kala I Pada Ibu Primipara Di Garut. [Tesis]. Jakarta: Universitas Indonesia.

Hartono, Radyanto Iwan Widya. 2012. Akupresur Untuk Berbagai Penyakit. Yogyakarta: Rapha Publishing.

Hastono, Sutanto Priyo dan Luknis Sabri. 2010. Statistik Kesehatan. Jakarta: Rajawali Pers.

Kementrian Kesehatan. 2014. Pusat Data Dan Informasi. Jakarta Selatan

Maryunani, Anik. 2010. Nyeri Persalinan. Jakarta: EGC.

Maternity, Dainty et al. 2016. Asuhan Kebidanan Persalinan. Tangerang Selatan: Binarupa Aksara Publisher.
4,00 (4 kali dalam 10 menit) dan maksimal 5,00 (5 kali kontraksi dalam 10 menit).

3. Maka hasil uji statistik didapatkan nilai $p$ value $=0,000<0,05$, maka dapat disimpulkan ada pengaruh yang signifikan antara peningkatan kontraksi sebelum pemijatan L14 dan sesudah pemijatan L14 pada ibu Inpartu kala I fase aktif.

\section{SARAN}

Hasil penelitian ini bagi lahan praktik atau BPM dapat dijadikan sebagai salah satu alternatif bahwa pemijatan pada titik L14 yang diberikan pada ibu Inpartu pada kala I fase aktif mempengaruhi peningkatan kontraksi, sehingga dapat mempercepat proses persalinan dan tanpa efek samping yang membahayakan.

Notoatmodjo, Soekidjo. 2014. Metodologi Penelitian Kesehatan. Jakarta: Rineka Cipta.

Rohani, et al. 2011. Asuhan Kebidanan Pada Masa Persalinan. Jakarta: Salemba Medika.

Rukiyah, Ai Yeyeh dan Lia Yulianti. 2014. Asuhan Kebidanan Patologi. Jakarta: TIM.

Sulistyawati, Ari Dan Esti Nugraheny. 2012. Asuhan Kebidanan Pada Ibu Bersalin. Jakarta: Salemba Medika.

Sunarsih, Ernawati. 2017. Perbedaan terapi Massage dan Terapi Relaksasi dalam mengurangi nyeri persalinan di Bidan Praktik Swasta (BPS) Ernawati Kecamatan Banyumas. Jurnal Kesehatan, Volume VIII No.I P-ISSN 20867751.

Walyani, Elisabeth Siwi, dan Endang Purwastuti. 2016. Asuhan Kebidanan Persalinan dan Bayi Baru Lahir.Yogyakarta: Pustaka Baru Press. 